Division of Geological \& Geophysical Surveys

RAW-DATA FILE 2014-23

\title{
GEOLOGIC NOTES ON GRANITE MOUNTAIN, MOUNT HAYES D-3 QUADRANGLE, ALASKA
}

\author{
Diana N. Solie and Melanie B. Werdon
}

$\$ 2.00$

DECEMBER 2014

THIS REPORT HAS NOT BEEN REVIEWED FOR TECHNICAL CONTENT OR FOR CONFORMITY TO

THE EDITORIAL STANDARDS OF DGGS

Released by

STATE OF ALASKA

DEPARTMENT OF NATURAL RESOURCES

Division of Geological \& Geophysical Surveys 3354 College Road

Fairbanks, Alaska 99709-3707 



\section{TABLE OF CONTENTS}

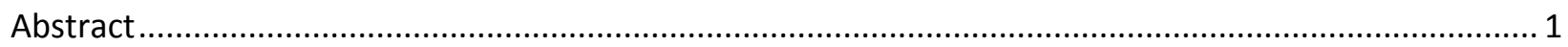

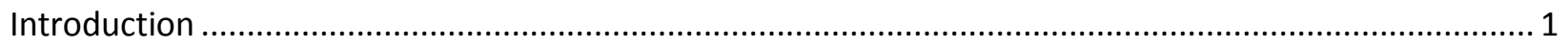

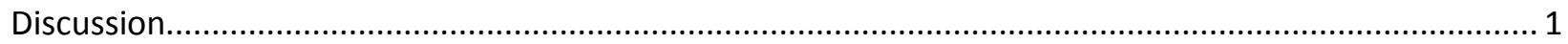

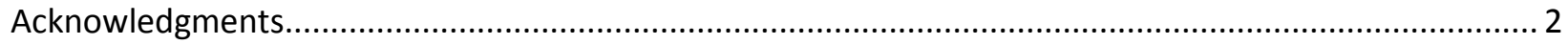

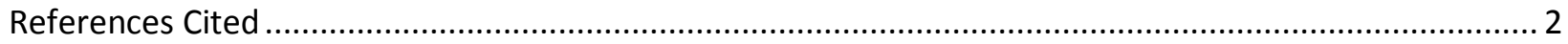

\section{FIGURES}

Figure 1. Location map showing field stations in red. The Alaska Highway corridor was the focus of DGGS geologic study from 2006 through 2012.......................................................................... 3

Figure 2. Field station locations on north side of Granite Mountain, Mount Hayes D-3 Quadrangle .......... 4 


\title{
GEOLOGIC NOTES ON GRANITE MOUNTAIN, MOUNT HAYES D-3 QUADRANGLE, ALASKA
}

by

Diana N. Solie ${ }^{1}$ and Melanie B. Werdon ${ }^{2}$

\begin{abstract}
In 2006-2007, Alaska Division of Geological \& Geophysical Surveys (DGGS) geologists traversed and collected rock samples from ridges on the north side of Granite Mountain in the Mount Hayes D-3 Quadrangle. Observed rocks include both fine-grained and medium-grained biotite-hornblende tonalite and granodiorite in contact with slivers of quartzite. Granitic and gabbroic dikes cut the plutonic rocks.
\end{abstract}

\section{INTRODUCTION}

DGGS conducted a multi-year project (from 2006 through 2010) studying the geology and geologic hazards along the Alaska Highway corridor (Solie and Burns, 2007). As part of the bedrock geologic mapping, traverses were conducted in the corridor on the north side of Granite Mountain (fig. 1). DGGS is publishing bedrock geologic maps of the Alaska Highway corridor farther east, from the Little Gerstle River area to the Canada border as three separate maps (Werdon and others, in press, Little Gerstle River to Dot Lake; Werdon and others, in press, Dot Lake to Tetlin Junction; Solie and others, in press, Tetlin Junction to Canada border). Surficial geology of the Alaska Highway corridor from Delta Junction to the Canada border is mapped by Reger and others $(2008,2011,2012)$.

This report covers bedrock geologic observations between Delta Junction and Little Gerstle River, for an area not included in the map areas described above. Station locations are shown in figure 2. Geochemical analyses from one of these samples (2007MBW1076A) and major-oxide and trace-element analyses from two others (2007MBW1067A and 2007MBW1087A) have been published previously (Solie and others, 2008). The digital data files for this report provide station locations and observations recorded in the geologists' field notes. In the digital data, definitive rock names are given for samples for which relative amounts of quartz, plagioclase, and alkali-feldspar were estimated based on stained slabs. The data points were collected using hand-held GPS devices using NAD 27 datum. The horizontal position error of sample locations in this report is in the range of 1 to 10 meters.

The data tables associated with this report are being released in digital format as comma-delimited text (CSV) files. Additional details about the files can be found in the metadata file associated with the digital version of this report, which is available from the DGGS website (doi:10.14509/29141) at no charge.

\section{Discussion}

Holmes and Péwé (1965) published a geologic map of the Mount Hayes D-3 Quadrangle that shows the Granite Mountain massif as granitic rocks (map unit gr). Nokleberg and others (1992a) refer to it as "Granite of Granite Mountain" (map unit grgm), describing it as biotite-hornblende granite with minor

${ }^{1}$ Baseline Geoconsulting, LLC, P.O. Box 82293, Fairbanks AK 99708-2293

${ }^{2}$ Alaska Division of Geological \& Geophysical Surveys, 3354 College Road, Fairbanks AK 99709-3707 
quartz diorite. They report a U-Pb zircon age of 90 Ma on the granite (Nokleberg and others, 1992b). DGGS traverses in 2007 added details regarding variations in texture and lithology. Fine- to mediumgrained granodiorite and medium- to coarse-grained tonalite appear to be in contact with each other on the ridges north of Granite Mountain. Mafic enclaves are common; mafic and felsic dikes transect the plutonic rocks. Slices of quartzite are either in faulted or intrusive contact within the pluton.

\section{ACKNOWLEDGMENTS}

This project was supported by Alaska State Capital Improvement Project funds. Field observations used in this report were made by Melanie Werdon of DGGS and visiting Nevada Bureau of Mines and Geology geologist James E. Faulds.

\section{References Cited}

Holmes, G.W., and Péwé, T.L., 1965, Geologic map of the Mt. Hayes D-3 quadrangle, Alaska: U.S. Geological Survey Geologic Quadrangle Map 366, 1 sheet, scale 1:63,360.

Nokleberg, W.J., Aleinikoff, J.N., Lange, I.M., Silva, S.R., Miyaoka, R.T., Schwab, C.E., and Zehner, R.E., 1992a, Preliminary geologic map of the Mount Hayes quadrangle, eastern Alaska Range, Alaska: U.S. Geological Survey Open-File Report 92-594, 39 p., 1 sheet, scale 1:250,000.

Nokleberg, W.J., Aleinikoff, J.N., Dutro, J.T., Jr., Lanphere, M.A., Silberling, N.J., Silva, S.R., Smith, T.E., and Turner, D.L., 1992b, Map, tables, and summary of fossil and isotopic age data, Mount Hayes quadrangle, eastern Alaska Range, Alaska: U.S. Geological Survey Miscellaneous Field Studies Map 1996-D, 43 p., 1 sheet, scale 1:250,000.

Reger, R.D., Stevens, D.S.P., and Solie, D.N., 2008, Surficial-geologic map, Delta Junction to Dot Lake, Alaska Highway corridor: Alaska Division of Geological \& Geophysical Surveys Preliminary Interpretive Report 2008-3A, 48 p., 2 sheets, scale 1:63,360. doi:10.14509/17961

Reger, R.D., Hubbard, T.D., and Carver, G.A., 2011, Surficial geology of Alaska Highway corridor, Robertson River to Tetlin Junction, Alaska: Alaska Division of Geological \& Geophysical Surveys Preliminary Interpretive Report 2009-6A, 53 p., 4 sheets, scale 1:63,360. doi:10.14509/19741

Reger, R.D., Hubbard, T.D., and Gallagher, P.E., 2012, Surficial geology of the Alaska Highway corridor, Tetlin Junction to Canada border, Alaska: Alaska Division of Geological \& Geophysical Surveys Preliminary Interpretive Report 2012-1A, 25 p., 2 sheets, scale 1:63,360. doi:10.14509/23443

Solie, D.N., and Burns, L.E., 2007, Alaska Highway corridor geology and geophysics: Alaska GeoSurvey News, v. 10 , no. 1 , p. 1-4.

Solie, D.N., Werdon, M.B., Newberry, R.J., Freeman, L.K., and Lessard, R.R., 2008, Major-oxide, minoroxide, trace-element and geochemical data from rocks collected in the Alaska Highway corridor, Mount Hayes Quadrangle, Alaska, in 2006 and 2007: Alaska Division of Geological \& Geophysical Surveys Raw Data File 2008-2 v. 1.0.1, 23 p. doi:10.14509/16021

Solie, D.N., Werdon, M.B., Freeman, L.K., Newberry, R.J., Szumigala, D.J., Speeter, G.G., and Elliott, B.A., in press, Bedrock-geologic map, Alaska Highway corridor, Tetlin Junction to Canada border, Alaska: Alaska Division of Geological \& Geophysical Surveys, Report of Investigations. 
Werdon, M.B., Solie, D.N., Newberry, R.J., Freeman, L.K., Elliott, B.A., and Lessard, R.R., in press, Bedrockgeologic map, Alaska Highway corridor, Little Gerstle River to Dot Lake, Alaska: Alaska Division of Geological \& Geophysical Surveys, Report of Investigations.

Werdon, M.B., Solie, D.N., Andrew, J.E., Freeman, L.K., Newberry, R.J., Szumigala, D.J., and Elliott, B.A., in press, Bedrock-geologic map, Alaska Highway corridor, Dot Lake to Tetlin Junction, Alaska: Alaska Division of Geological \& Geophysical Surveys, Report of Investigations.

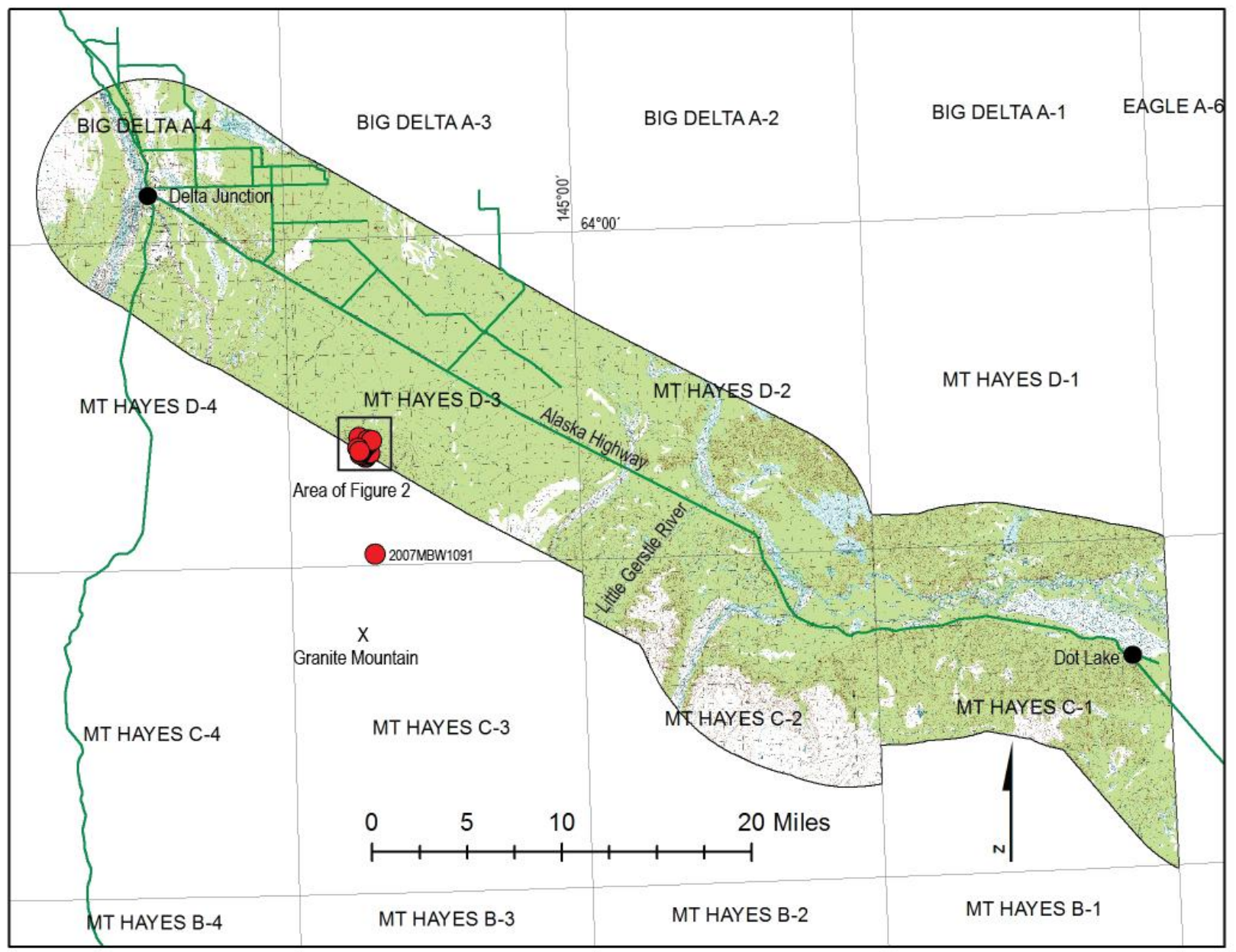

Figure 1. Location map showing field stations in red. The Alaska Highway corridor was the focus of DGGS geologic study from 2006 through 2012. 


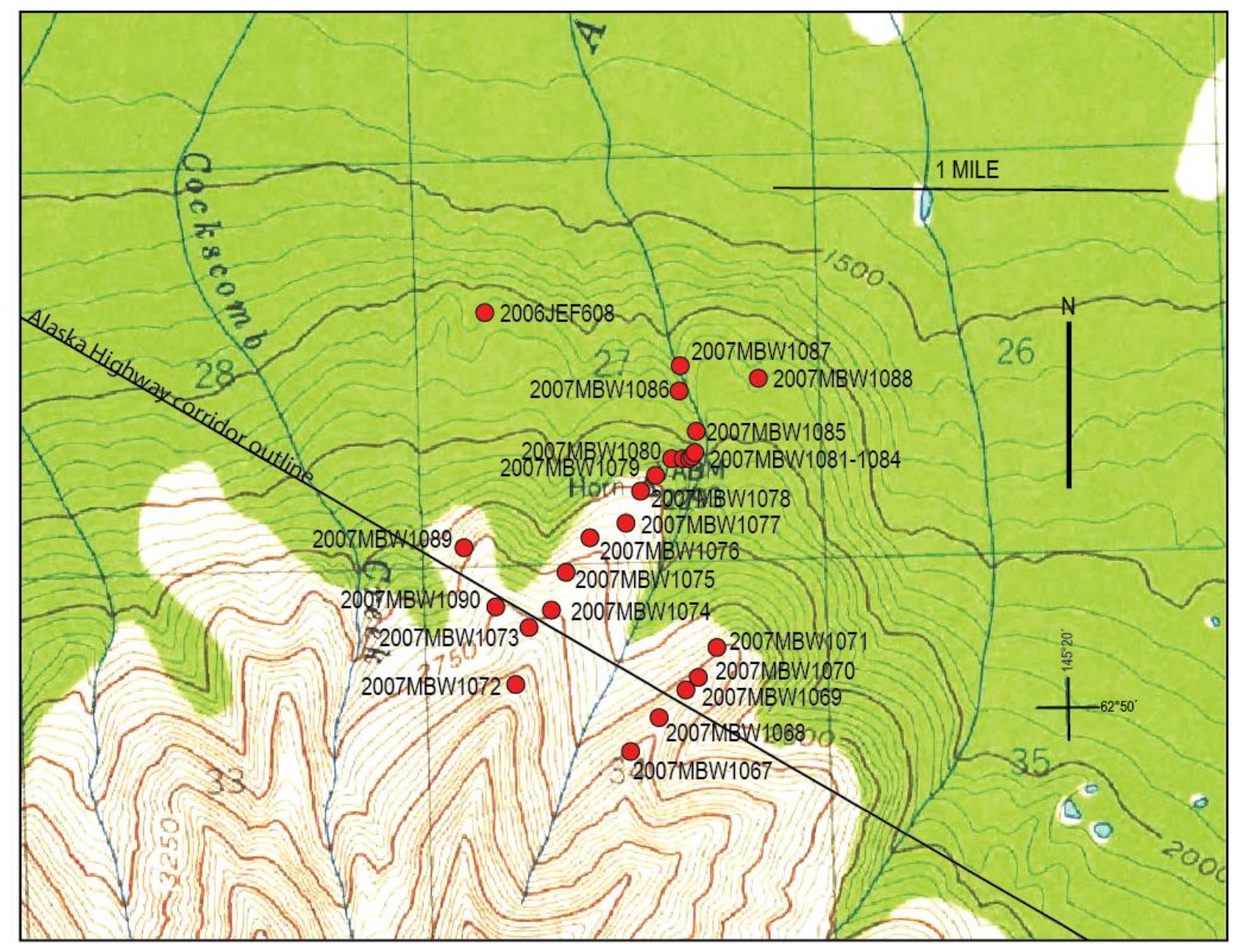

Figure 2. Field station locations on north side of Granite Mountain, Mount Hayes D-3 Quadrangle 